Don W. SPRINGER*

\title{
TELL US NO SECRETS: ST. IRENAEUS' CONTRA-GNOSTIC DOCTRINE OF COMMUNION
}

Toward the end of the second century the concept of communion with God emerged as a topic of interest in both early Christian and Gnostic literature. This paper briefly examines the relevant contributions of Irenaeus of Lyons and aims to identify how they compare to the analogous Gnostic presuppositions. I will argue that while Irenaeus shared with his opponents an emphasis on communion as the potentiality for personal union with God, he is distinguished by his paradigm outlining how the potential is realized ${ }^{1}$.

1. Gnostic Communion. When Irenaeus first introduced his readers to the topic of communion he did so with specific reference to heretical cosmology. Indeed, throughout Books 1 and 2 of Adversus haereses allusions to communion primarily concerned the beliefs of the heretics. In these chapters Irenaeus detailed a variety of gnostic groups and their teachings and was careful to demonstrate the many disparities among them. Despite the diversity of thought, there is generally one element common to Gnostic communion. This I shall summarize in great brevity and with admitted generalization ${ }^{2}$. For the Gnostics, the subject of communion began with the relationship between the Pleroma and the Aeons. Emanating from the Pleroma - the highest divine source - were the Aeons: divine offspring (for lack of a better term). The emanations came forth

* Don W. Springer - PhD Cand. and sessional Instructor at McMaster Divintiy College in Hamilton, Ontario, Canada; e-mail: dwspringer@gmail.com.

${ }^{1}$ For this study, "communion" is the favoured expression, following the Latin manuscripts' use of communio. The original Greek would most likely have been koinonia. For a discussion, see B.C. Blackwell, Christosis: Pauline Soteriology in Light of Deification in Irenaeus and Cyril of Alexandria, Tübingen 2011, 61-63.

${ }^{2}$ For a more thorough introduction, see N.D. Lewis, Introduction to "Gnosticism": Ancient Voices, Christian Worlds, New York 2013; D. Brakke, The Gnostics: Myth, Ritual, and Diversity in Early Christianity, Cambridge 2010. Concerning Irenaeus' interactions with and faithfulness to his opponents' teachings see G.S. Smith, Guilt by Association: Heresy Catalogues in Early Christianity, Oxford 2014, 131-171; G. Chiapparini, Irenaeus and the Gnostic Valentinus: Orthodoxy and Heresy in the Church of Rome Around the Middle of the Second Century, ZACh 18 (2014) 95-119; L. Ayres, Irenaeus vs. the Valentinians: Toward a Rethinking of Patristic Exegetical Origins, JECS 23 (2015) 153-187; Lewis, Introduction, p. 63-65. 
in twos, with each pair being further removed from the Pleroma than the ones before. Sophia was an Aeon in the final coupling and was thus most distant from the divine source. According to Irenaeus, Sophia was most displeased with her distant position. The Valentinians in particular stressed Sophia's unrest and intense desire for "communion with the perfect Father" here to summarize sufficiently the entire cosmological narrative, nor the rest of Sophia's sordid part in the story ${ }^{4}$, but the important point can nevertheless be simply stated. It was the idea of a desire for greater intimacy with God that provided the context for Irenaeus' initial use of the term communion.

A move from cosmology to anthropology provides a second context for understanding the present subject. For the purposes of this paper, the point of central interest is the manner in which Irenaeus described the heretics' understanding of humanity's ability to experience divine union. He again argued there were significant discrepancies between them, but he failed to provide extensive evidence supporting the claim. His purpose was to focus primarily on one key and foundational presupposition: the assertion that humanity's ascent to God was possible only through the reception of pure and authentic knowledge. This gnosis, typically secret and only selectively revealed, was the means by which one could find union with the divine. This, according to Irenaeus, was the heart of Gnostic communion ${ }^{5}$. In the Valentinian Gospel of Truth the term "communion" is not used, but the concept is nonetheless present. In paragraphs nine and ten there is a clear congruency between the possession of knowledge with humanity's possible connection to God:

${ }^{3}$ The Valentinian belief, according to Irenaeus, stated: "In like manner, the rest of the Aeons also, in a kind of quiet way, had a wish to behold the Author of their being, and to contemplate that First Cause which had no beginning. But there rushed forth in advance of the rest that Aeon who was the latest of them, and was the youngest of the Duodecad which sprang from Anthropos and Ecclesia, namely Sophia, and suffered passion apart from the embrace of her consort Theletos. This passion, indeed, first arose among those who were connected with Nous and Aletheia, but passed as by contagion to this degenerate Aeon, who acted under a pretence of love, but was in reality influenced by temerity, because she had not, like Nous, enjoyed communion with the perfect Father. This passion, they say, consisted in a desire to search into the nature of the Father; for she wished, according to them, to comprehend his greatness", cf. Irenaeus, Adversus haereses, I 2.2, ed. A. Rousseau - L. Doutreleau, SCh 264, Paris 1979, 38-39; ibidem II 18, 7, SCh 294, Paris 1982, 184. Translations modified from existing English texts, in consultation with the "Sources Chrétiennes" critical editions. English translations referenced include The Apostolic Fathers with Justin Martyr and Irenaeus, ed. A. Roberts - J. Donaldson - A. Cleveland Coxe, ANF 1, Grand Rapids 1987; M.C. Steenberg, St. Irenaeus of Lyons Against the Heresies, ACW 64, New York 1992..

${ }^{4}$ For a recent study summarizing the emergence of Sophia in Valentinian cosmology, see C.S. O'Brien, The Demiurge in Ancient Thought, Cambridge 2015. See also R.A. Norris, Who Is the Demiurge?: Irenaeus' Picture of God in Adversus Haereses 2, in: God in Early Christian Thought: Essays in Memory of Lloyd G. Patterson, ed. A.B. McGowan - B.E. Daley - T.J. Gaden, Supplements to VigChr 94, Leiden 2009, 9-36.

${ }^{5}$ On the secrecy of Gnosticism see R.M. Grant, Irenaeus of Lyons, London 1997, 9-14 and 17-18. 
"Since the perfection of the All is in the Father, it is necessary for the All to ascend to him. Therefore, if one has knowledge, he gets what belongs to him and draws it to himself. For he who is ignorant, is deficient, and it is a great deficiency, since he lacks that which will make him perfect. Since the perfection of the All is in the Father, it is necessary for the All to ascend to him and for each one to get the things which are his. He registered them first, having prepared them to be given to those who came from him. Those whose name he knew first were called last, so that the one who has knowledge is he whose name the Father has pronounced [...] Hence, if one has knowledge, he is from above. If he is called, he hears, he replies, and he turns toward him who called him and he ascends to him and he knows what he is called".

Although it is a sweeping generalization to so simply characterize the disparate heterodox groups, in this instance Irenaeus does not seem far off the mark with his assessment. Therefore, Gnostic communion will be defined as the teaching on divine intimacy as secured through secret knowledge ${ }^{7}$. The task moving forward is to identify the alternative paradigm as proposed by Irenaeus.

2. Irenaean Communion. Discussion of "orthodox" communion is spread throughout the final three books of Adversus haereses. Like the Gnostics, Irenaeus placed great importance on the need for possession of authentic truth. But whereas his opponents emphasized secrecy and exclusivity, Irenaeus argued the content of the truth was to be found in the publicly taught, universally held rule of faith. He provides perhaps his most clear formulation in the sixth chapter of his Epideixis. The rule, which he referred to as the foundation and the stabilizing force of the faith, was ordered by three central points:

"God, the Father, not made, not material, invisible; one God, the creator of all things: this is the first point of our faith. Second: The Word of God, Son of God, Christ Jesus our Lord [...] through whom all things were made; who also at the end of the times, to complete and gather up all things, was made man among men, visible and tangible, in order to abolish death, reveal life, and produce a community of union between God and man. Third point: The Holy Spirit, through whom the prophets prophesied, and the fathers learned the things of God, and the righteous were led into the way of righteousness; and who in the end of the times was poured out in a new way upon mankind in all the earth, renewing man unto God"s.

${ }^{6}$ Evangelium veritatis 9-10, transl. R.M. Grant, in: idem, Gnosticism: A Source Book of Heretical Writings from the Early Christian Period, New York 1961, 149-150

${ }^{7}$ For further insight into the subject, see N. Deutsch, The Gnostic Imagination: Gnosticism, Mandaeism and Merkabah Mysticism, Leiden 1995.

${ }^{8}$ Irenaeus, Demonstratio praedicationis apostolicae 6, ed. S. Weber, Friburgi Brisgoviae 1917, 31-32. Translation based on that by J. Behr: St Irenaeus of Lyons, On the Apostolic Preaching, Crestwood 1997, 43-44. 
The important elements of Irenaeus' doctrine of communion are all present in this text. Contra Gnostic cosmology and spirituality stands the assertion of the one creator God, his Word through whom all was created and in whom revelation, salvation, and communion are made possible. Moreover, it is the Spirit of God that draws humankind into such possibilities 9 . At the heart of both Irenaeus' theology and his critique of heresy is the incarnation of the Word, and the manner in which the salvific work of the Word recapitulates humanity and, indeed, all of creation to himself. Christ, the true image of God restores the divine image and likeness to God's people through his coming. This counters the Gnostic scheme distinguished by the Pleroma and emanating Aeons. Of the key elements noted in Gnostic communion - the cosmological and anthropologi$\mathrm{cal}$ - the remainder of this paper will focus strictly on the latter. To narrow the investigation further still, I will primarily seek to identify the practical dimensions of Irenaean communion ${ }^{10}$. This seems warranted by the fact that despite its robust, ground-breaking theological reflection, Adversus haereses is very much a pastoral treatise. Indeed, one of Irenaeus' central concerns was promoting the potential relationship between God and humanity. There are three key principles which continually reappear; three elements put forth as essential for humanity to take engage in the mystical journey with God. These are, first, the necessity of the indwelling of the Spirit of God, second, participation in the true Church, and third, participation in the life of virtue ${ }^{11}$.

3. Life in the Spirit. Whereas the Gnostics taught the need for reception of gnosis, Irenaeus stressed that the truly important reception occurred at Pentecost. With the Spirit comes two key developments integral to divine communion: perfection and vivification. Not to belabour the point, but again, the Gnostics associated perfection with the possession of gnosis. Irenaeus, however, made very clear his departure from this position. Referencing

${ }^{9}$ The classic treatment of Irenaeus' doctrine of the Trinity remains J. Lebreton, Histoire $d u$ dogme de la Trinité des origines au Concile de Nicée, Paris 1928. For more recent treatments, see M.R. Barnes, Irenaeus' Trinitarian Theology, NV 7 (2009) 67-106; J. Lashier, Irenaeus on the Trinity, Leiden 2014.

${ }^{10}$ Although Adversus haereses placed extraordinary emphasis on the importance of the incarnation and of man's creation in the divine likeness, it should be noted that cosmological issues, such as divine generation, for example, are not seriously reflected upon. Though the Gnostics put forth their understanding of the emanations and inter-divine relations, Irenaeus was less concerned, even insofar as it would relate to the Trinity.

${ }^{11}$ The relationship between the doctrines of the incarnation, rededmption, and recapitulation with anthropology are crucial in Irenaeus' theology. Several of the most important $20^{\text {th }}$ century English works that examine these dynamics include F.R.M. Hitchcock, Irenaeus of Lugdunum: A Study of His Teaching, Cambridge 1914; G. Wingren, Man and the Incarnation: A Study in the Theology of Irenaeus, transl. R. Mackenzie, Edinburgh 1959; J. Behr, Asceticism and Anthropology in Irenaeus and Clement, Oxford 2000; E. Osborn, Irenaeus of Lyons, Cambridge 2001; M.C. Steenberg, Irenaeus on Creation: The Cosmic Christ and the Saga of Redemption, Leiden 2008. 
1 Corinthians, he repeats the Pauline assertion that, "we speak wisdom among them that are perfect", but he has an alternative perspective of how perfection is achieved. He states that:

"the «perfect» are those who have received the Spirit of God. [...] they are spiritual because they partake of the Spirit, and not because their flesh has been stripped off and taken away, and because they have become purely spiritual. [...] when the spirit here blended with the soul is united to (God's) handwork, the man is rendered spiritual and perfect because of the outpouring of the Spirit" $"$.

According to Adversus haereses, it is reception of the Spirit that leads to perfection, and thus, to intimacy with the divine. The process is not, however, an instantaneous one. Although the presence of the Spirit marks one as spiritual, it is for Irenaeus only the beginning of the journey. He affirmed that a process of "vivification" begins for those that truly possess the divine gift ${ }^{13}$. With this idea, all of the Irenaean emphases are united: communion, intimacy with God, knowledge, divine likeness, salvation - they each find fulfillment in the work of the Spirit of God. Irenaeus summarized the entirety of his thought by simply stating that the Spirit brings life.

"For as the flesh is capable of corruption, so is it also of incorruption; and as it is of death, so is it also of life. These two do mutually give way to each other [...] life, when it has obtained power over the man, drives out death, and restores him as living unto God. For if death brings mortality, why should not life, when it comes, vivify man?"'

The active, present tense of the text is clear: those renewed, those re-united to God are spiritual not through received knowledge alone but through the indwelling presence of the Spirit. Moreover, because of the potency of that presence the believer is in process of being made alive. The concept of life in the Spirit is not intended to be only theoretical. Life in the Spirit is, after all, a teaching about actually living life ${ }^{15}$. Irenaeus therefore turned to explicitly practical matters as he discussed the second and third themes of the life of communion. For Irenaeus, to have renewed life with God and to be vivified by the Spirit requires two key areas of participation: life in the true Church, and a life of virtue.

${ }^{12}$ Irenaeus, Adversus haereses V 6, 1, ed. A. Rousseau - L. Doutreleau - Ch. Mercier, SCh 153, Paris 1969, 72-74.

${ }^{13}$ Cf. ibidem IV 21, 3, ed. A. Rousseau - B. Hemmerdinger - L. Doutreleau - Ch. Mercier, SCh 100/2, Paris 1965, 683-684.

${ }^{14}$ Ibidem V 12, 1, SCh 100/2, Paris 1965, 140-141.

${ }^{15}$ For recent, detailed discussion of the role of the Holy Spirit in Irenaeus, see A. Briggman, Irenaeus of Lyons and the Theology of the Holy Spirit, Oxford 2012; idem, The Holy Spirit as the Unction of Christ in Irenaeus, JTS 61 (2010) 171-193. 
4. Life in Community. According to the bishop of Lugdunum, spiritual formation and communion with God depend on the Church because Christ's Church is the exclusive domain for all that is truly spiritual. In Irenaeus' mind there is no truth or authenticity outside the institution established by the Lord's apostles. He stated it simply:

"The blessed apostles [...] founded and built up the Church [...] and by this order and succession we have received from the apostles the church's tradition and the preaching of the truth. And this is greatest proof that there is one and the same vivifying faith, which has been preserved in the Church from the apostles until now, and has been handed down in truth"16.

He affirmed elsewhere that in view of such evidence, it is not necessary to seek the truth amongst others when it is easy to obtain from the Church; since the apostles, like a rich man (depositing his money) in a bank, lodged in her hands most copiously all things pertaining to the truth: so that every man can draw from her the water of life. For she is the entrance to life ${ }^{17}$. In view of the spread of heresy, such exclusive claims are unsurprising. His apologetic motivations, do not, however, negate the affirmative, essential role that the Church plays in his theology of communion. Congregational affiliation with the orthodox churches was not noteworthy only because of an enviable position of historic continuity with Lord and apostles; of greater significance was that "life" was there entered into. The Church is thus firstly a spiritual, not institutional entity. He urged:

"flee to the Church, and be brought up in her bosom, and be nourished with the Lord's Scriptures. For the Church has been planted as a paradise in this world [...] Into this paradise the Lord has introduced those who obey His call, summing up in Himself all things [...] These things, therefore, He recapitulated in Himself: by uniting man to the Spirit, and causing the Spirit to dwell in man, He is Himself made the head of the Spirit, and gives the Spirit to be the head of man: for through Him we see, and hear, and speak"18.

Communion with God through life in the Spirit takes place in the one, true Church. In view of the context of communion, unity, and spiritual nourishment, it is not surprising that Irenaeus also stressed the critical place of the Eucharist. Orthodox scholar John Behr sees Irenaeus clearly putting forth the idea that the church is literally "nourished from the cup which is his blood and replenished by the bread which is his body"19. In terms of participation in the life of in the

${ }^{16}$ Irenaeus, Adversus haereses III 3, 3, ed. A. Rousseau - L. Doutreleau, SCh 211, Paris 1974, 33.38. Irenaeus' views on apostolic tradition, the rule of faith, and episcopal succession are important to this discussion, but outside the scope of this study. See J. Behr, The The Way to Nicaea, Crestwood 2006; J. Pelikan, The Christian Tradition: A History of the Development of Doctrine, vol. 1: The Emergence of the Catholic Tradition (100-600), Chicago 1971.

${ }^{17}$ Cf. Irenaeus, Adversus haereses III 4, 1, SCh 211, 44.

${ }^{18}$ Ibidem V 20, 2, SCh 153, 259-260.

${ }^{19}$ Behr, Asceticism and Anthropology, p. 72. 
church, the onus is upon the individual to recognize the need for nourishment from Christ within the community of God's people. This is participation in the vivification process by repeatedly dying to self, the renunciation of that which the Word came to expel. Behr refers to this as Eucharistic, or "baptismally living" 20 . It is one, critical component of Irenaeus' belief that true life and communion with God occurs solely in the context of the Church.

5. The Life of Virtue. The final component to Irenaeus' spiritual life concerns the manner in which the community was called to live in relation to one another and to the world. The call upon both the Church and her individual members is the same: all are called to participate through a life of virtue and moral living. Virtue may be an unexpected element in the formula for the life of communion with God. But Behr sees this as a natural element to the Irenaean paradigm. He argues that virtue, for Irenaeus, is from God, "who deploys his strength in the weakness of human flesh, and is thus manifested in human beings when they lead their lives in obedience to the Spirit, who alone makes them spiritual"21. Virtue invites intimacy with God. Such a life can be summarized as incorporating two key elements: humility and morality. To be humble before God, Irenaeus stated, requires the Christian to:

"Offer to Him the heart in a soft and teachable state [...] maintain your originally created form and you will ascend to that which is perfect, for the moist clay which is in you is hidden within by the workmanship of God. His hand fashioned your substance; He will cover you over inside and out with pure gold and silver, and He will adorn you to such a degree, that even the King Himself shall have pleasure in your beauty"22.

The first step of virtue is transparency and openness before God; transparency to admit one's need, and openness to receive the grace of God. The life of intimacy begins with the obedience to humble oneself before this King. The second element to virtue is the life of obedience and morality. Four brief texts summarize this element of Irenaean theology. The promise is made that the omniscient God will kindly confer:

First: "that light which they desire on those who seek after the light of incorruption" $"$.

Second: "It is therefore one and the same God the Father who has prepared good things with Himself for those who desire His fellowship, and who remain in subjection to Him"24.

\footnotetext{
${ }^{20}$ Cf. idem, The Trinitarian Being of the Church, VTQ 48 (2003) 86.

${ }^{21}$ Idem, Asceticism and Anthropology, p. 124.

${ }^{22}$ Irenaeus, Adversus haereses IV 39, 1, SCh 100/2, 967.

${ }^{23}$ Ibidem IV 39, 4, SCh 100/2, 970,

${ }^{24}$ Ibidem IV 40, 1, SCh 100/2, 974.
} 
Third: "Those, then, are the perfect who have had the Spirit of God remaining in them, and have preserved their souls and bodies blameless, holding fast the faith of God, that is, that faith which is [directed] towards God, and maintaining righteous dealings with respect to their neighbours" 25 .

And fourth: "to as many as continue in their love towards God, does He grant communion with Him. But communion with God is life and light, and the enjoyment of all the benefits which He has in store"26.

Desire, obedience, perseverance, faith, righteousness, and love are each put forth as necessary elements for a life with God. Irenaeus did not express these as optional or especially blessed gifts or abilities, but as the required, virtuous traits of any who desire to commune with the divine. This emphasis on virtue stands in contrast to what Irenaeus claimed was the tendency of the Gnostics. Their knowledge and perfection, he suggested, allowed all manner of worldly, immoral behavior ${ }^{27}$. Moreover, their $\gamma \nu \hat{\omega} \sigma ı \mathrm{~s}$ could, he alleged, be acquired not at the cost of holy living, but with a payment of the fiscal variety ${ }^{28}$.

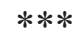

Irenaeus and the Gnostics shared an important belief about communion: they both taught that intimacy with the divine was possible. Where they differed was in the practical application concerning how the possibility was achieved. Speaking very generally, the Gnostic paradigms were defined by the insistence on the need for reception of secret $\gamma \nu \hat{\omega} \sigma ı$. Irenaeus, however, envisioned the journey towards God as a progressive ascent: one participated in through the indwelling of the Spirit, in the true Church, committed to the life of holy virtue. Although Gnostic teachings no doubt contributed to Irenaeus employing the terminology and concerns of communion, his paradigm was a radical departure in every respect.

\section{(Summary)}

Discussion related to the potential for mystical union with God was largely absent from the writings of the Church Fathers prior to the late-second century. Toward the end of that century, however, the concept of communion with God emerged as a topic of interest in both early Christian and Gnostic literature. St. Irenaeus of Lyons was among the earliest Christian writers to critically reflect on the subject. He argued that participation with the divine was possible only in the

\footnotetext{
${ }^{25}$ Ibidem V 6, 1 SCh 153, 80.

${ }^{26}$ Ibidem V 27, 2, SCh 153, 343.

${ }^{27}$ Cf. ibidem I 6, 2-4, SCh 264, 92-100.

${ }^{28}$ Cf. ibidem I 4, 3, SCh 264, Paris 1979, 68.
} 
"orthodox" churches and required three key elements: a life lived in connection to the Spirit of God, in community with the true people of God, while bearing evidence of godly piety and virtue. Whereas Gnostic conceptions of communion frequently included an emphasis on the reception of an exclusive, secret gnosis, Irenaeus' paradigm offered a public, progressive path of ascent to God.

\section{MÓW DO NAS BEZ ŻADNYCH TAJEMNIC: ANTYGNOSTYCKA KONCEPCJA ZJEDNOCZENIA ŚW. IRENEUSZA}

\section{(Streszczenie)}

Dyskusje na temat możliwości mistycznego zjednoczenia z Bogiem były w większości nieobecne w pismach Ojców Kościoła przed końcem II wieku. Dopiero u schyłku tego wieku pojęcie komunii z Bogiem stało się przedmiotem zainteresowania zarówno literatury wczesnochrześcijańskiej, jak i gnostyckiej. Ireneusz z Lyonu był jednym z pierwszych pisarzy chrześcijańskich, który podjął krytyczną refleksję nad tym zagadnieniem. Twierdził, że uczestnictwo w boskości jest możliwe tylko w prawowiernych Kościołach i wymaga trzech kluczowych elementów: życia przeżywanego w relacji z Duchem Bożym, we wspólnocie z prawdziwymi ludźmi Bożymi, i jednocześnie dającymi świadectwo religijnej pobożności i cnoty. Podczas gdy gnostyckie koncepcje zjednoczenia kładły często nacisk na zastrzeżona, tajemną wiedzę, paradygmat Ireneusza oferował publiczną, progresywną drogę wznoszenia się do Boga.

Key words: Irenaeus of Lyon, Adversus haereses, gnostics, communion.

Słowa kluczowe: Ireneusz z Lyonu, Adversus haereses, gnostycy, wspólnota.

\section{BIBLIOGRAPHY}

\section{Sources}

Irenaeus, Adversus haereses, ed. A. Rousseau - L. Doutreleau - B. Hemmerdinger - Ch. Mercier, I, SCh 263-264, Paris 1979; II, SCh 293-294, Paris 1982; III, SCh 210 211, Paris 1974; IV, SCh 100/1-2, Paris 1965; V, SCh 152-153, Paris 1969.

Irenaeus, Demonstratio praedicationis apostolicae, ed. S. Weber, Friburgi - Brisgoviae 1917.

\section{Literature}

Ayres L., Irenaeus vs. the Valentinians: Toward a Rethinking of Patristic Exegetical Origins, JECS 23 (2015) 153-87.

BARNES M.R., Irenaeus's Trinitarian Theology, NV 7 (2009) 67-106.

BeHR J., Asceticism and Anthropology in Irenaeus and Clement, Oxford 2000.

BeHR J., St Irenaeus of Lyons. On the Apostolic Preaching, Crestwood 1997.

BeHR J., The Trinitarian Being of the Church, VTQ 48 (2003) 67-88.

BeHR J., The Way to Nicaea, Crestwood 2006. 
Blackwell B.C., Christosis: Pauline Soteriology in Light of Deification in Irenaeus and Cyril of Alexandria, Tübingen 2011.

Brakke D., The Gnostics : Myth, Ritual, and Diversity in Early Christianity, Cambridge 2010.

Briggman A., Irenaeus of Lyons and the Theology of the Holy Spirit, Oxford 2012.

Briggman A., The Holy Spirit as the Unction of Christ in Irenaeus, JTS 61 (2010) 171-193.

ChIAPPARINI G., Irenaeus and the Gnostic Valentinus: Orthodoxy and Heresy in the Church of Rome Around the Middle of the Second Century, ZACh 18 (2014) 95-119.

Deutsch N., The Gnostic Imagination: Gnosticism, Mandaeism and Merkabah Mysticism, Leiden 1995.

Grant R.M., Irenaeus of Lyons, London 1997.

Grant R.M., Gnosticism: A Source Book of Heretical Writings from the Early Christian Period, New York 1961.

Hiтснсоск F.R.M., Irenaeus of Lugdunum: A Study of His Teaching, Cambridge 1914.

LASHIER J., Irenaeus on the Trinity, Leiden 2014.

Lebreton J., Histoire du dogme de la Trinité des origines au Concile de Nicée, vol. 2, Paris 1928.

Lewis N.D., Introduction to "Gnosticism”: Ancient Voices, Christian Worlds, New York 2013.

Norris R.A., Who Is the Demiurge?: Irenaeus'Picture of God in Adversus Haereses 2, in: God in Early Christian Thought: Essays in Memory of Lloyd G. Patterson, ed. A.B. McGowan - B.E. Daley - T.J. Gaden, Supplements to VigChr 94, Leiden 2009, 9-36.

O'Brien C.S., The Demiurge in Ancient Thought, Cambridge 2015.

OsBorn E., Irenaeus of Lyons, Cambridge 2001.

Pelikan J., The Christian Tradition: A History of the Development of Doctrine, vol. 1: The Emergence of the Catholic Tradition (100-600), Chicago 1971.

Sмiтн G.S., Guilt by Association: Heresy Catalogues in Early Christianity, Oxford 2014.

Steenberg M.C., Irenaeus on Creation: The Cosmic Christ and the Saga of Redemption, Leiden 2008.

Wingren G., Man and the Incarnation: A Study in the Theology of Irenaeus, transl. R. Mackenzie, Edinburgh 1959. 